\title{
Taxonomic revision of the Savanna Nightjar (Caprimulgus affinis) complex based on vocalizations reveals three species
}

\author{
George Sangster ${ }^{*^{*}} \mathbb{0}$, Kim Manzon Cancino ${ }^{2}$ and Robert O. Hutchinson ${ }^{3}$
}

\begin{abstract}
Background: The Savanna Nightjar (Caprimulgus affinis) is a widespread, polytypic species which was previously treated as two or three species. It is currently treated as a single species based on superficial similarity of their songs but no detailed comparisons of the songs in this complex have been made.

Methods: A total of 15 acoustic variables were measured for the songs of 86 individuals representing 8 of the 10 subspecies in the complex.

Results: Three major groups can be distinguished based on univariate and multivariate analyses: a northern group consisting of the subspecies C. a. monticolus, C. a. amoyensis and C. a. stictomus; a southern group consisting of $C$. a. affinis, C. a. kasuidori, C. a. timorensis and C. a. propinquus; and a third group in the Philippines consisting of C. a. griseatus.
\end{abstract}

Conclusions: It is here argued that these groups are best treated as species, and that Franklin's Nightjar (C. monticolus) and Kayumanggi Nightjar (C. griseatus) are reinstated as separate species.

Keywords: Caprimulgidae, Macrogeograpic variation, Taxonomy, Vocalizations

\section{Background}

Most species of nightjars and owls have a cryptic plumage which has long hampered taxonomic study of their species limits. During the last two decades, quantitative comparisons of songs have helped clarify species limits in several groups, including pygmy owls [Glaucidium [Howell and Robbins 1995; Gwee et al. 2019)], scops owls [Otus (Rasmussen et al. 2000; Sangster et al. 2013)], screech owls [Megascops (Krabbe 2017; Dantas et al. 2021)], hawk owls (Ninox [Rasmussen et al. 2012; Gwee et al. 2017]) and nightjars [Caprimulgus ([Sangster and Rozendaal 2004)]. Three aspects make songs in these groups useful for taxonomic purposes. First, in nearly

*Correspondence: g.sangster@planet.nl

${ }^{1}$ Naturalis Biodiversity Center, Darwinweg 2, PO Box 9517, 2300 RA Leiden, The Netherlands

Full list of author information is available at the end of the article all groups of non-passerines songs, including owls and nightjars, are not known to be learned (Kroodsma 2004). Variation is therefore likely inherited and may provide information about evolutionary relationships. Second, in some species of owls and nightjars songs are known to be involved in intra- and interspecific communication (reviewed by Sangster and Rozendaal 2004). This makes their songs a useful indicator of species limits (Marshall 1978). Third, songs in both groups are rather simple and stereotypical (Marshall 1978), which makes homology assessment easy. Vocalizations are therefore a useful avenue for clarifying and refining species limits in other species of nightbirds.

The Savanna Nightjar (Caprimulgus affinis Horsfield, 1821 ) is widely distributed in the Oriental region, ranging from northern Pakistan to Indonesia and TimorLeste (Fig. 1). The song of the species is distinctive and can be described as a rasping "tschreep" note. Whereas 


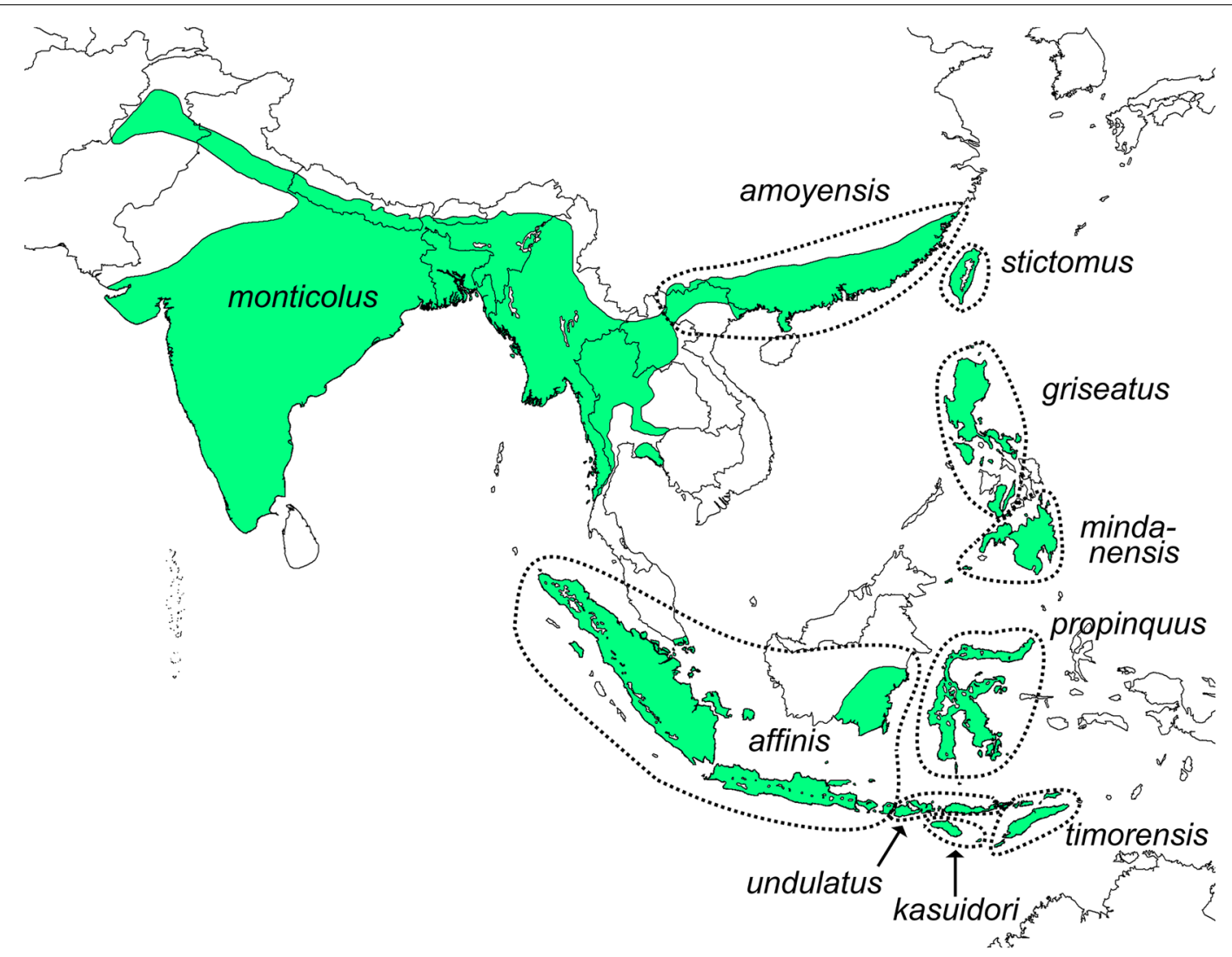

Fig. 1 Range map of Caprimulgus affinis (based on BirdLife International and Handbook of the Birds of the World 2017), indicating subspecies limits (sensu Cleere 1998). The taxa undulatus Mayr, 1944 and kasuidori Mayr, 1944 were included in C. a. affinis by Mees (2006) and Dickinson and Remsen (2013)

geographic variation in the vocalizations of Large-tailed Nightjar (C. macrurus Horsfield, 1821) has long been known (Marshall 1978) and has been used to delimit species (Mees 1985; Rozendaal 1990; Sangster and Rozendaal 2004), no such knowledge exists for $C$. affinis.

In the early twentieth century, taxonomic authorities recognized C. monticolus Franklin, 1831 and C. affinis as separate specis, the former occurring on mainland Asia and the latter in southern Peninsular Malaysia, Singapore and Indonesia east to Timor-Leste (Sharpe 1901; Peters 1940). Sharpe (1901) also recognized C. griseatus as a species. While discussing a letter from Erwin Stresemann on the birds of Yunnan, China, Rothschild (1927) noted that he disagreed with Stresemann that $C$. monticolus and C. affinis were conspecific. Mayr (1944) noted that the plumage of the Philippine taxon C. a. griseatus Walden, 1875 was intermediate between that of C. monticolus and C. affinis and regarded them as a single species. Sibley and Monroe (1990) ackowledged the occasional treatment of C. monticolus and C. affinis as species but noted that their calls are identical. These three opinions have formed the basis for recognizing a single species, a treatment which is now universally adopted in field guides (King et al. 1975; Robson 2000; Rasmussen and Anderton 2005; Allen 2020; Eaton et al. 2021), handbooks (Cleere 1998; Holyoak 2001) and taxonomic lists (Wolters 1976; Inskipp et al. 1996; Clements 2007; Dickinson and Remsen 2013; del Hoyo and Collar 2014; Gill et al. 2020). The only exception were Howard and Moore (1991), who presumably followed Peters (1940) in treating C. monticolus as a distinct species.

In this study, we revisit species limits in C. affinis using bioacoustic data on eight of the ten subspecies recognized by Cleere (1998) and Holyoak (2001).

\section{Methods}

Recordings were obtained from the Xeno-Canto (http:// www.xeno-canto.org/) and AVoCet (http://avocet.zoolo gy.msu.edu/) databases, and the bird sound collections of the Florida Museum of Natural History (https://www. floridamuseum.ufl.edu/bird-sounds/) and the British Library Sound Archive (http://cadensa.bl.uk/). The data set was supplemented by published recordings (Marshall 1978; Ranft and Cleere 1998; Jännes 2002; Supari 2003; 
Scharringa 2005; Chappuis et al. 2009) and our own recordings, which we submitted to the Macaulay Library (https://www.macaulaylibrary.org/). In total, songs of 86 individuals of 8 of the 10 subspecies of $C$. affinis (sensu Cleere 1998; Holyoak 2001) were available for analysis: C. a. monticolus (34 individuals), C. a. amoyensis (2), C. a. stictomus (11), C. a. affinis (21), C. a. kasuidori (1), C. a. timorensis (5), C. a. propinquus (1) and C. a. griseatus (11). A list of recordings with localities and recordists is provided in Additional file 1: Table S1.

A total of 15 variables was defined on the basis of sonagrams (Fig. 2). The following measurements were recorded: (1) F1, frequency at the start of the song; (2) F2, frequency at the first low; (3) F3, frequency at the second peak; (4) F4, frequency at the second low; (5) F5, frequency at the third peak; (6) F6, maximum frequency, which is the highest frequency present; (7) F7, minimum frequency, which is the lowest frequency present; (8) DF1, the frequency drop between the second peak and the second low; (9) DF2, the frequency drop between the second and third peaks; (10) DF3, frequency range, which is the difference between the maximum and minimum frequency; (11) DT1, total song duration; (12) DT2, the duration of the first downward element at the point where the song begins to increase in frequency; (13) DT3, the interval between the second peak and the end of the song; (14) DT4, the interval between the second and third peaks; and (15) DT5, the interval between the first and second peaks. The first ten of these (F1 to DF3) are frequency-related variables, whereas the last five (DT1DF5) are time-related variables.

Principal Component Analysis (PCA) was used to reduce the 15 acoustic variables to a limited number of uncorrelated variables. ANOVA was used to test whether the groups defined by PCA differed from each other.

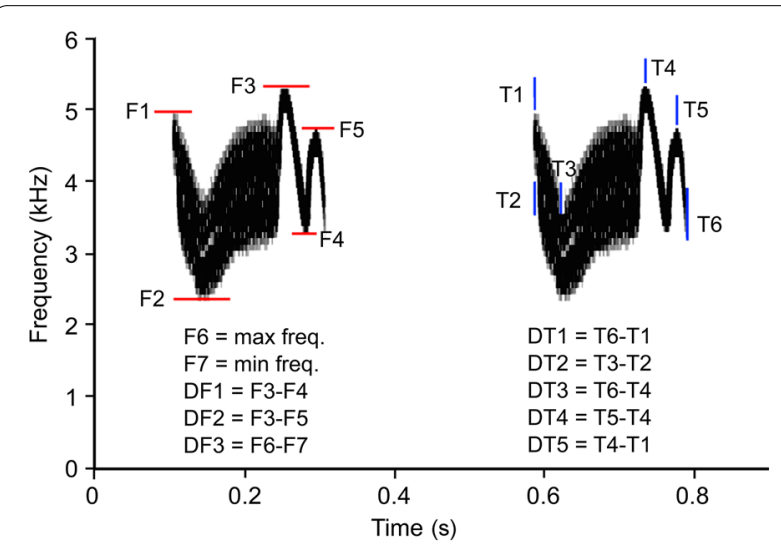

Fig. 2 Measurement of song variables. The left sonagram shows the frequency parameters and the right sonagram shows the time parameters
Canonical Discriminant Function Analysis (DFA) was applied to the acoustic variables of individuals to test whether the individuals could be correctly assigned to the groups defined by PCA. DFA generates a set of criteria to assign individuals to groups that are defined prior to the analysis. Prior to DFA analysis, a tolerance test was conducted to assess the independence of each variable. Variables that failed the tolerance test, i.e. which are an almost linear combination of other variables, were excluded from the analyses. Two DFAs were performed: (i) a "descriptive" DFA, in which the observations used to develop the criteria are then subjected to these criteria; (ii) a "predictive" DFA, which uses a jackknife procedure to obtain a more accurate test of the predictive performance of the DFA. In the jackknife procedure, the DFA is recalculated using the combination of variables of the initial DFA with one individual removed from the data set. The criteria are then used to classify the removed individual. This process was repeated for all individuals of the data set.

The effect size, expressed as Cohen's $d$, was calculated to show the strength of the acoustic differences between taxa. For interpretation of effect size data, we used the classification of Cohen (1988), which was updated and expanded by Sawilowsky (2009). Thus, we regard an effect size of $d \geq 0.1$ as "very small", $d \geq 0.2$ as "small", $d \geq 0.5$ as "medium", $d \geq 0.8$ as "large", $d \geq 1.2$ as "very large" and $d \geq 2.0$ as "huge".

SPSS version 27.0 (IBM Corp 2020) was used to calculate all descriptive statistics and perform analyses of variance (ANOVA), Mann-Whitney U-tests, Principal Components Analyses, and Discriminant Function Analyses.

\section{Results}

\section{Principal component analysis}

The songs of 86 individuals were used in the PCA. The results of the PCA on the 15 measurements are summarized in Table 1. Four components with eigenvalues $>1$ were extracted from the data set. The first principal component (PC1) accounted for $46.0 \%$ of the variance. PC2, PC3 and PC4 accounted for an additional 24.0, 12.0, and 9.1\% of the variance, respectively. PC1 was represented by most frequency variables, especially $\mathrm{F} 3$ and F6, and DF1. PC2 was determined mostly by F2 and F3, and PC3 mostly by DT 1 and DT5.

Plotting individuals on $\mathrm{PC} 1$ versus $\mathrm{PC} 2$ revealed three distinct clusters, corresponding to songs from the affinis-group (subspecies C. a. affinis, C. a. kasuidori, C. a. timorensis and C. a. propinquus), the monticolusgroup (subspecies C. a. monticolus, $C$. a. amoyensis and C. a. stictomus) and the griseatus-group (subspecies $C$. 
Table.1 Factor loadings of 15 acoustic variables on the 4 principal components in the Caprimulgus affinis complex. Eigenvalues and percentage of variance explained by the respective components are given at the bottom of the table

\begin{tabular}{lllll}
\hline Variable & PC1 & PC2 & PC3 & PC4 \\
\hline F1 & 0.788 & 0.341 & 0.110 & -0.261 \\
F2 & 0.129 & 0.905 & -0.239 & 0.202 \\
F3 & 0.940 & 0.194 & 0.212 & 0.156 \\
F4 & 0.080 & 0.595 & 0.582 & -0.440 \\
F5 & 0.693 & 0.467 & 0.384 & -0.315 \\
F6 & 0.941 & 0.194 & 0.217 & 0.146 \\
F7 & 0.129 & 0.905 & -0.239 & 0.202 \\
DF1 & 0.910 & -0.084 & -0.060 & 0.365 \\
DF2 & 0.826 & -0.097 & -0.001 & 0.491 \\
DF3 & 0.847 & -0.338 & 0.352 & 0.025 \\
DT1 & -0.636 & -0.046 & 0.621 & 0.417 \\
DT2 & 0.634 & -0.321 & -0.325 & 0.224 \\
DT3 & -0.660 & 0.566 & 0.190 & 0.349 \\
DT4 & -0.688 & 0.554 & 0.159 & 0.333 \\
DT5 & -0.230 & -0.578 & 0.641 & 0.227 \\
\hline Eigenvalue & 6.906 & 3.599 & 1.795 & 1.372 \\
Variance explained & $46.0 \%$ & $24.0 \%$ & $12.0 \%$ & $9.1 \%$ \\
F (ANOVA) & 8606 & 6604 & 15.0 & 15.1 \\
Significance (ANOVA) & $P<0.001$ & $P<0.001$ & $P<0.001$ & $P<0.001$ \\
Degrees of freedom (ANOVA) & 85 & 85 & 85 & 85 \\
\hline
\end{tabular}
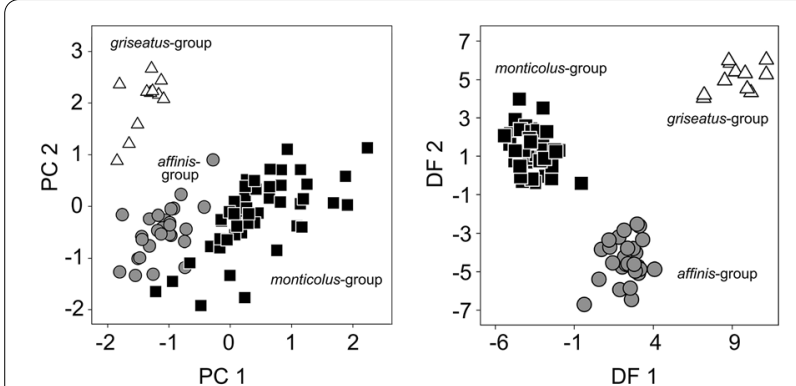

Fig. 3 PCA (left) and DFA (right) scatterplots of acoustic variables measured for songs of the Caprimulgus affinis complex $(n=86)$

a. griseatus) (Fig. 3). One-way ANOVA showed that the three groups identified by PCA differed in all four principal components (Table 1).

\section{Discriminant function analysis}

The songs of the three groups identified by PCA were used in the DFA. Most variables passed the tolerance test, except F7, DF1, DF2, DF3 and DT5 which were excluded from the test. The descriptive DFA was highly significant (Wilks' lambda $=0.004$; Chi Square ${ }_{20}=435.6 ; P<0.001$ ). The variables most important in the discrimination were
Table.2 Standardized canonical discriminant function coefficients examining trends in variance of ten acoustic variables measured for songs of three groups of Caprimulgus affinis

\begin{tabular}{lcc}
\hline Variable $^{\mathrm{a}}$ & DF1 & DF2 \\
\hline F1 & 0.109 & 0.079 \\
F2 & 0.150 & 1.428 \\
F3 & 2.608 & 1.556 \\
F4 & 1.025 & -1.148 \\
F5 & -0.412 & -0.711 \\
F6 & -3.294 & -0.561 \\
DT1 & 0.109 & -0.275 \\
DT2 & -0.441 & 0.389 \\
DT3 & 0.093 & 0.195 \\
DT4 & 0.930 & 0.120 \\
Eigenvalue & 20.270 & 11.082 \\
Variance explained & $64.7 \%$ & $35.3 \%$
\end{tabular}

Eigenvalues and percentage of variance accounted for by DF1 and DF2 are given at the bottom of the table

${ }^{a}$ Variables F7, DF1, DF2, DF3 and DT5 were excluded because these failed the tolerance test

F2, F3, F4, F6 and DT4 (Table 2). The initial DFA led to a $100 \%$ correct classification of the individuals into the three groups. The jackknife procedure also provided a high degree of predictive discrimination, with 85 of $86(98.8 \%)$ individuals being correctly assigned to their group defined by PCA.

\section{Univariate analysis}

Song characteristics of the three groups identified by PCA are given in Table 3 and illustrated in Fig. 4. All 15 variables differed significantly in comparisons of the monticolus-group with the affinis-group, and some of these also showed non-overlapping ranges (DF1 and DF2 in monticolus-group vs. affinis-group. Similarly, 14 variables differed significantly in comparisons of the monticolus-group with the griseatus-group, and 4 (DF1, DF3, DT3 and DT4) showed no overlap. Comparisons of the affinis-group with the griseatus-group revealed seven significant differences and five variables that showed no overlap between the 2 groups (F2, F7, DF3, DT3 and DT4).

The effect size of the differences between the three groups is given in Table 3 . The three groups showed multiple "very large" (Cohen's $d>1.2$ ) or "huge" (Cohen's $d>2.0$ ) differences in both frequency-related and timerelated variables (Table 3 ).

The differences between the three groups are visible on sonagrams (Fig. 4). The songs of the griseatusgroup differ most prominently from the monticolus- and affinis-groups by their lack of a raspy quality (shown on 
Table.3 Descriptive statistics of 15 variables measured for songs of 3 species in the Caprimulgus affinis complex (mean \pm SD, range)

\begin{tabular}{|c|c|c|c|c|c|c|}
\hline Variable & $\begin{array}{l}\text { C. monticolus } \\
(n=47)\end{array}$ & C. affinis $(n=28)$ & C. griseatus $(n=11)$ & $\begin{array}{l}\text { C. monticolus vs. C. affinis } \\
\text { Significance } \\
\text { Cohen's } d \text { (interpretation) }\end{array}$ & $\begin{array}{l}\text { C. monticolus vs. C. } \\
\text { griseatus Significance } \\
\text { Cohen's } d \\
\text { (interpretation) }\end{array}$ & $\begin{array}{l}\text { C. affinis vs. } \\
\text { C. griseatus } \\
\text { Significance } \\
\text { Cohen's } d \\
\text { (interpretation) }\end{array}$ \\
\hline F1 & $\begin{array}{l}5139 \pm 394 \\
(4033-6262)\end{array}$ & $\begin{array}{l}4726 \pm 205 \\
(4366-5161)\end{array}$ & $\begin{array}{l}4780 \pm 281 \\
(4115-5074)\end{array}$ & $\begin{array}{l}P<0.001^{b} \\
\left.1.25 \text { ("very large }^{\prime \prime}\right)^{d}\end{array}$ & $\begin{array}{l}P<0.005^{b} \\
0.97\left({ }^{\prime} \text { large" }\right)^{c}\end{array}$ & $\begin{array}{l}\text { n.s. } \\
0.25\left(\text { ("small") }{ }^{c}\right.\end{array}$ \\
\hline F2 & $\begin{array}{l}2242 \pm 206 \\
(1712-2720)\end{array}$ & $\begin{array}{l}1856 \pm 195 \\
(1435-2332)\end{array}$ & $\begin{array}{l}2948 \pm 150 \\
(2663-3156)\end{array}$ & $\begin{array}{l}P<0.001^{b} \\
1.94(\text { "very large") })^{c, d}\end{array}$ & $\begin{array}{l}P<0.001^{\text {b }} \\
3.64(\text { "huge") }\end{array}$ & $\begin{array}{l}P<0.001^{b} \\
6.10 \text { ("huge") }^{d}\end{array}$ \\
\hline F3 & $\begin{array}{l}5773 \pm 627 \\
(4514-7399)\end{array}$ & $\begin{array}{l}4879 \pm 269 \\
(4366-5587)\end{array}$ & $\begin{array}{l}5034 \pm 249 \\
(4503-5264)\end{array}$ & $\begin{array}{l}P<0.001^{b} \\
1.73(" \text { very large" })^{c, d}\end{array}$ & $\begin{array}{l}P<0.001^{b} \\
1.30 \text { ("very large") }^{c, d}\end{array}$ & $\begin{array}{l}\text { n.s. } \\
0.60(\text { ("medium") }\end{array}$ \\
\hline $\mathrm{F} 4$ & $\begin{array}{l}3428 \pm 303 \\
(2859-4088)\end{array}$ & $\begin{array}{l}3634 \pm 273 \\
(3256-4403)\end{array}$ & $\begin{array}{l}3685 \pm 246 \\
(3243-4091)\end{array}$ & $\begin{array}{l}P<0.005^{\mathrm{a}} \\
0.71 \text { ("medium") }^{c}\end{array}$ & $\begin{array}{l}P<0.001^{b} \\
\left.0.89\left({ }^{(1 a r g e}\right)^{\prime \prime}\right)^{c}\end{array}$ & $\begin{array}{l}\text { n.s. }^{\text {a }} \\
0.20\left(\text { ("small") }{ }^{c}\right.\end{array}$ \\
\hline F5 & $\begin{array}{l}4931 \pm 416 \\
(4079-5799)\end{array}$ & $\begin{array}{l}4723 \pm 235 \\
(4376-5374)\end{array}$ & $\begin{array}{l}4746 \pm 287 \\
(4143-5082)\end{array}$ & $\begin{array}{l}P<0.001^{b} \\
0.59\left(" m e d i u m^{\prime}\right)^{c}\end{array}$ & $\begin{array}{l}\text { n.s. }{ }^{\text {b }} \\
0.47\left({ }^{\prime \prime} \text { small") }\right)^{c}\end{array}$ & $\begin{array}{l}\text { n.s. } \\
0.10 \text { ('very small') }^{c}\end{array}$ \\
\hline F6 & $\begin{array}{l}5777 \pm 630 \\
(4514-7399)\end{array}$ & $\begin{array}{l}4895 \pm 253 \\
(4505-5587)\end{array}$ & $\begin{array}{l}5034 \pm 249 \\
(4503-5264)\end{array}$ & $\begin{array}{l}P<0.001^{b} \\
1.71 \text { ("very large") }^{c, d}\end{array}$ & $\begin{array}{l}P<0.001^{b} \\
1.30 \text { ("very large") }^{c, d}\end{array}$ & $\begin{array}{l}\text { n.s. } \\
0.57 \text { ("medium") }^{c}\end{array}$ \\
\hline F7 & $\begin{array}{l}2242 \pm 206 \\
(1712-2720)\end{array}$ & $\begin{array}{l}1856 \pm 195 \\
(1435-2332)\end{array}$ & $\begin{array}{l}2948 \pm 150 \\
(2663-3156)\end{array}$ & $\begin{array}{l}P<0.001^{\mathrm{a}} \\
1.94(\text { "very large") })^{c, d}\end{array}$ & $\begin{array}{l}P<0.001^{\mathrm{b}} \\
3.64(\text { "huge") }\end{array}$ & $\begin{array}{l}P<0.001^{b} \\
6.10 \text { ("huge") }^{d}\end{array}$ \\
\hline DF1 & $\begin{array}{l}2345 \pm 463 \\
(1618-3486)\end{array}$ & $\begin{array}{l}1246 \pm 187 \\
(647-1563)\end{array}$ & $\begin{array}{l}1349 \pm 184 \\
(1035-1617)\end{array}$ & $\begin{array}{l}P<0.001^{b} \\
2.90(\text { "huge") }\end{array}$ & $\begin{array}{l}P<0.001^{b} \\
2.37(\text { "huge") }\end{array}$ & $\begin{array}{l}\text { n.s. }{ }^{\text {b }} \\
0.57 \text { ("medium") }^{c}\end{array}$ \\
\hline DF2 & $\begin{array}{l}842 \pm 389 \\
(407-1914)\end{array}$ & $\begin{array}{l}156 \pm 109 \\
(-175-324)\end{array}$ & $\begin{array}{l}288 \pm 83 \\
(182-420)\end{array}$ & $\begin{array}{l}P<0.001^{b} \\
2.20(\text { ("huge") })^{d}\end{array}$ & $\begin{array}{l}P<0.001^{b} \\
1.59 \text { ("very large") }^{c, d}\end{array}$ & $\begin{array}{l}P<0.001^{b} \\
1.32(\text { ("very large") })^{c, d}\end{array}$ \\
\hline DF3 & $\begin{array}{l}3535 \pm 587 \\
(2543-4956)\end{array}$ & $\begin{array}{l}3039 \pm 237 \\
(2608-3496)\end{array}$ & $\begin{array}{l}2087 \pm 204 \\
(1710-2338)\end{array}$ & $\begin{array}{l}P<0.001^{\mathrm{b}} \\
1.03\left({ }^{\prime \prime} \text { large }\right)^{\prime \prime}\end{array}$ & $\begin{array}{l}P<0.001^{\mathrm{b}} \\
2.73\left(\text { ("huge") }^{\mathrm{d}}\right.\end{array}$ & $\begin{array}{l}P<0.001^{\mathrm{b}} \\
4.28 \text { ("huge" }^{\mathrm{d}}\end{array}$ \\
\hline DT1 & $\begin{array}{l}0.194 \pm 0.020 \\
(0.154-0.245)\end{array}$ & $\begin{array}{l}0.226 \pm 0.017 \\
(0.197-0.276)\end{array}$ & $\begin{array}{l}0.230 \pm 0.017 \\
(0.200-0.257)\end{array}$ & $\begin{array}{l}P<0.001^{b} \\
1.75 \text { ("very large") }^{c, d}\end{array}$ & $\begin{array}{l}P<0.001^{b} \\
1.92(\text { ("very large") })^{c, d}\end{array}$ & $\begin{array}{l}\text { n.s. }{ }^{\text {a }} \\
0.23\left({ }^{\text {("small") }} \text { c }\right.\end{array}$ \\
\hline DT2 & $\begin{array}{l}0.023 \pm 0.004 \\
(0.015-0.035)\end{array}$ & $\begin{array}{l}0.014 \pm 0.002 \\
(0.010-0.018)\end{array}$ & $\begin{array}{l}0.012 \pm 0.003 \\
(0.006-0.017)\end{array}$ & $\begin{array}{l}P<0.001^{\mathrm{a}} \\
2.58\left(\text { ("huge") }^{\mathrm{d}}\right.\end{array}$ & $\begin{array}{l}P<0.001^{\mathrm{b}} \\
2.69\left(\text { ("huge" }^{\mathrm{d}}\right)^{\mathrm{d}}\end{array}$ & $\begin{array}{l}\text { n.s. }{ }^{\text {b }} \\
0.59\left(\text { ("medium") }^{c}\right.\end{array}$ \\
\hline DT3 & $\begin{array}{l}0.050 \pm 0.006 \\
(0.035-0.066)\end{array}$ & $\begin{array}{l}0.065 \pm 0.007 \\
(0.048-0.073)\end{array}$ & $\begin{array}{l}0.098 \pm 0.008 \\
(0.080-0.106)\end{array}$ & $\begin{array}{l}P<0.001^{\text {a }} \\
2.33(\text { "huge") }\end{array}$ & $\begin{array}{l}P<0.001^{b} \\
7.34(\text { "huge") }\end{array}$ & $\begin{array}{l}P<0.001^{\mathrm{b}} \\
4.82(\text { "huge") }\end{array}$ \\
\hline DT4 & $\begin{array}{l}0.042 \pm 0.005 \\
(0.031-0.059)\end{array}$ & $\begin{array}{l}0.056 \pm 0.006 \\
(0.044-0.064)\end{array}$ & $\begin{array}{l}0.087 \pm 0.006 \\
(0.075-0.097)\end{array}$ & $\begin{array}{l}P<0.001^{\mathrm{b}} \\
2.91\left(\text { ("huge") }^{\mathrm{d}}\right.\end{array}$ & $\begin{array}{l}P<0.001^{\mathrm{b}} \\
9.13\left(\text { ("huge") }^{\mathrm{d}}\right.\end{array}$ & $\begin{array}{l}P<0.001^{\text {b }} \\
5.38(\text { ("huge") }\end{array}$ \\
\hline DT5 & $\begin{array}{l}0.144 \pm 0.016 \\
(0.119-0.184)\end{array}$ & $\begin{array}{l}0.162 \pm 0.017 \\
(0.134-0.209)\end{array}$ & $\begin{array}{l}0.132 \pm 0.015 \\
(0.117-0.155)\end{array}$ & $\begin{array}{l}P<0.001^{\mathrm{a}} \\
1.07\left({ }^{\prime \prime} \text { large }\right. \\
\end{array}$ & $\begin{array}{l}P<0.05^{\mathrm{b}} \\
0.79(\text { "medium") }\end{array}$ & $\begin{array}{l}P<0.001^{b} \\
1.90 \text { ("very large") }^{c, d}\end{array}$ \\
\hline
\end{tabular}

The right three columns present significance levels of ANOVA or Mann-Whitney U-tests, the effect size (expressed as Cohen's $d$ ) and the interpretation of effect size by Cohen (1988) and Sawilowsky (2009)

${ }^{a}$ ANOVA

${ }^{\mathrm{b}} \mathrm{MWU}$-test

c sensu Cohen (1988)

${ }^{d}$ sensu Sawilowsky (2009)

sonagrams as a narrow line in the first upward-inflected element). The differences between the monticolus- and affinis-groups are reflected by (i) the broader basis (i.e. longer duration) of the first downward element of the songs of the monticolus-group than in those of the affinisgroup, and in the much larger frequency drops between (ii) F3 and F4 and (iii) F3 and F5 in the monticolus-group.

\section{Discussion}

The results of this study show that the northern subspecies C. a. monticolus, C. a. amoyensis and C. a. stictomus, the southern subspecies $C$. a. affinis, $C$. a. kasuidori, $C$. a. timorensis and C. a. propinquus and the Philippine subspecies C. a. griseatus represent separate groups in Principal Component Analysis of variation in vocalizations, and that individuals can be classified correctly at high proportions in Discriminant Function Analysis. The three groups show significant differences in the three principal components and in all univariate variables and there are "very large" to "huge" differences in effect size between the three groups in both frequency-related and time-related variables.

The lack of evidence for vocal learning in most nonpasserines, including nightjars, implies that vocal differences are innate and likely have a genetic basis. Thus, population-level differences in vocalizations may reflect 


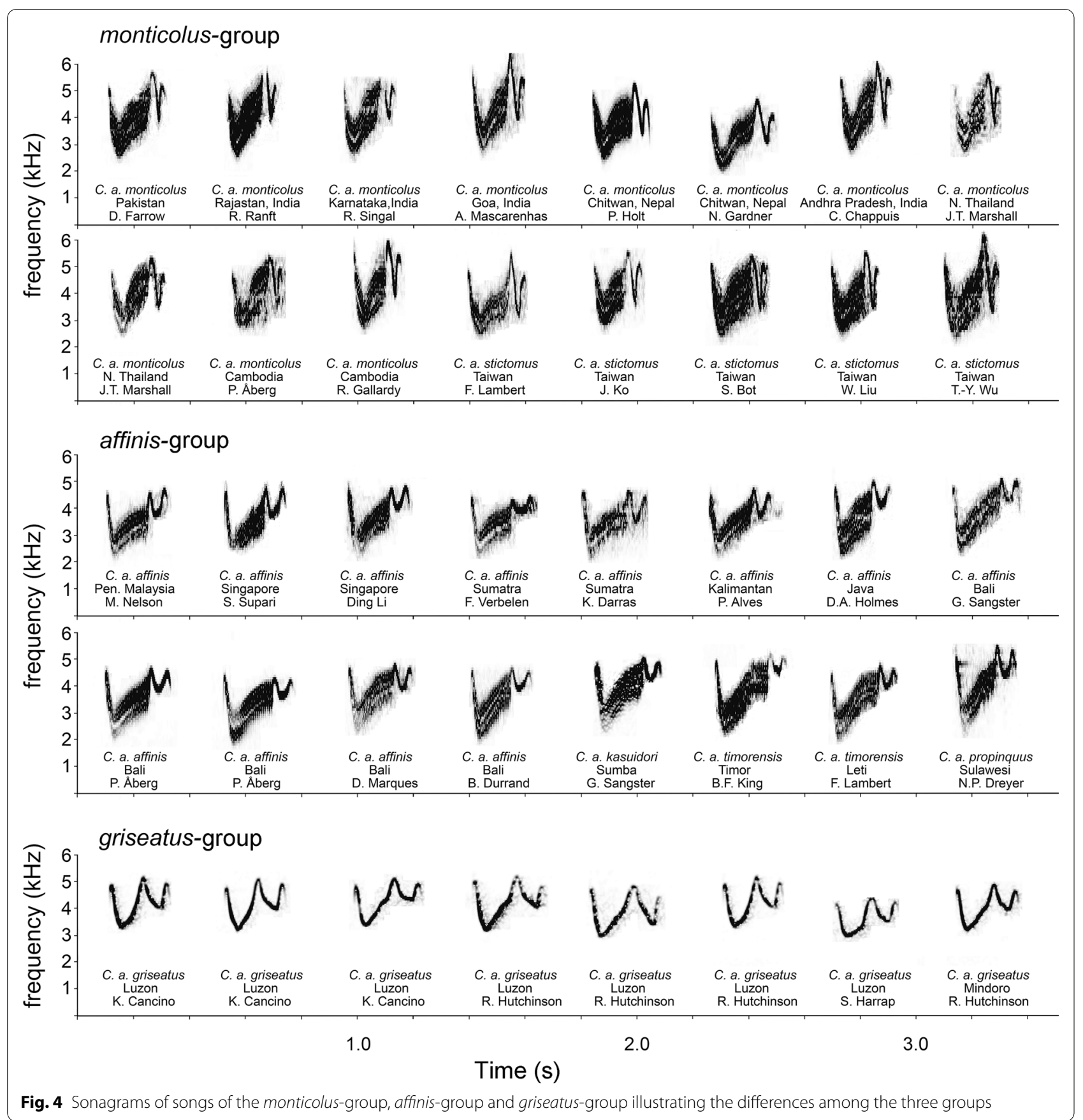

evolutionary divergence. The multiple differences documented between the geographically separate monticolus and affinis groups likely means that these populations have been subjected to a long period of genetic isolation. Consequently, the three non-overlapping groups in the DFA plot are therefore best interpreted as evidence that the monticolus-group, the affinis-group and the griseatus-group represent separate evolutionary lineages, i.e. separate branches in the tree of life. According to the
General Lineage Concept (de Queiroz 1999, 2007) such lineages are best considered as species: C. monticolus, C. affinis and C. griseatus. As English names we propose to reinstate the name Franklin's Nightjar for C. monticolus and to maintain Savanna Nightjar for C. affinis. For C. griseatus we suggest the name Kayumanggi Nightjar, in recognition of the Filipino name Kayumanggi for brownish-coloured, particularly with reference to tan coloured skin. The three species reinstate species last 
recognized by Sharpe (1901) and reflect differences in size and plumage coloration. C. monticolus is larger and browner than C. affinis (Cleere 1998). Indeed, data in Cleere (1998) show no overlap in wing length between C. monticolus (males 181-208 $\mathrm{mm}$; females 177$208 \mathrm{~mm}$ ) and C. affinis (males 150-172 mm; females $152-170 \mathrm{~mm}$ ). C. griseatus is greyer than C. affinis and the barring on its underparts is finer and extends lower on the belly (Cleere 1998; Holyoak 2001).

Unfortunately, no recordings were available of the Philippine taxon C. a. mindanensis Mearns, 1905. Thus, it is not clear if this taxon belongs to C. griseatus or to C. affinis, or perhaps represents another vocally distinct group. Pending further analysis, we suggest that $C$. $a$. mindanensis be treated as conspecific with $C$. griseatus on geographic grounds. We are not aware of any reliable recent records of $C$. $a$. mindanensis, and we hope our paper provides impetus to find and study this poorly known taxon.

Taxonomic study of the C. affinis complex, and that of other groups of nightjars, could further benefit from molecular phylogenetic and phylogeographic analyses. This could (i) corroborate and refine of species limits based on morphological or bioacoustic patterns, (ii) facilitate the discovery of additional lineages, and (iii) provide a historical perspective on the biogeography of the group. Conversely, modern morphological and bioacoustic studies of species limits may benefit phylogenetic and phylogeographic analyses by indicating which populations should be sampled and where additional cryptic species may be located.

\section{Conclusions}

In recent decades, avian species-level taxonomy shows two major trends: improved documentation of species taxa and a refinement of species limits. As a consequence, the scientific underpinnings of avian taxonomy continue to be improved and the number of taxonomically-recognized species increases steadily (Sangster and Luksenburg 2015; Sangster 2018). The increase of species is not a goal of taxonomy but results from the improved understanding of species limits due to new information on groups that often have long been neglected. This process is especially important in birds due to the large-scale lumping of species in the first half of the twentieth century without detailed study (reviewed by Haffer 1992; Sangster 2018). The Savanna Nightjar complex is an example of three valid species that have long been treated as a single species without a solid scientific basis. The results of this study thus underscore the importance of identifying and revisiting poorly-documented taxonomic changes.

\section{Supplementary Information}

The online version contains supplementary material available at https://doi. org/10.1186/s40657-021-00288-z.

Additional file 1: Table S1. Recording localities, recordists and accession numbers/sources.

\section{Acknowledgements}

We are grateful to the referees for their constructive comments on the manuscript, Ben F. King for sharing an unpublished recording from Timor, Desmond Allen for his help with obtaining recordings, Juan Carlos T. Gonzalez for his help with selecting a suitable English name for the Philippine species, and to all recordists who made their recordings available on Xeno-Canto, AVoCet, and the bird sound collections of the Florida Museum of Natural History and British Library Sound Archive.

\section{Authors' contributions}

GS conceived and designed the study, collated the data, performed analyses and wrote the manuscript. $\mathrm{KMC}$ and $\mathrm{ROH}$ contributed materials and improved the manuscript. All authors read and approved the final manuscript.

Funding

This study was funded by a grant from Mark Constantine.

\section{Availability of data and materials}

All but one of the recordings used in this study are available from the XenoCanto (http://www.xeno-canto.org/), AVoCet (http://avocet.zoology.msu.edu/) databases, and the bird sound collections of the Florida Museum of Natural History (https://www.floridamuseum.ufl.edu/bird-sounds/), Macaulay Library (https://www.macaulaylibrary.org/) and British Library Sound Archive (http:// cadensa.bl.uk/). One recording, by Ben F. King, will be archived at the Macaulay Library, Cornell University, NY, USA.

\section{Declarations}

Ethics approval and consent to participate Not applicable.

\section{Consent for publication}

Not applicable.

\section{Competing interests}

The authors declare that they have no competing interests.

\section{Author details}

${ }^{1}$ Naturalis Biodiversity Center, Darwinweg 2, PO Box 9517, 2300 RA Leiden, The Netherlands. ${ }^{2} 423$ N. Espino Street, Poblacion, Bugallon, Pangasinan, Philippines. ${ }^{3}$ Birdtour Asia Ltd, 26 Sutton Avenue, Chellaston, Derby DE73 6RJ, UK.

Received: 29 April 2021 Accepted: 13 October 2021

Published online: 28 October 2021

\section{References}

Allen D. Birds of the Philippines. Lynx and BirdLife International Field Guides. Barcelona: Lynx Edicions; 2020.

BirdLife International, Handbook of the Birds of the World (HBW). Bird species distribution maps of the world. Version 7.0. 2017. http://datazone.birdlife. org/species/requestdis.

Cleere N. Nightjars, a guide to nightjars and related nightbirds. Robertsbridge: Pica Press; 1998.

Clements JF. The Clements checklist of birds of the world. 6th ed. Ithaca: Cornell University Press; 2007.

Cohen J. Statistical power analysis for the behavioral sciences. 2nd ed. Hillsdale, NJ: Lawrence Earlbaum Associates; 1988.

IBM Corp. IBM SPSS statistics for windows, version 27.0. Armonk: IBM Corp; 2020. 
Dantas SM, Weckstein JD, Bates J, Oliveira JN, Catanach TA, Aleixo A. Multicharacter taxonomic review, systematics, and biogeography of the Blackcapped/Tawny-bellied Screech Owl (Megascops atricapilla-M. watsonii) complex (Aves: Strigidae). Zootaxa. 2021;4949:401-44.

de Queiroz K. The general lineage concept of species and the defining properties of the species category. In: Wilson RA, editor. Species: new interdisciplinary essays. Cambridge MA: MIT Press; 1999. p. 49-89.

de Queiroz K. Species concepts and species delimitation. Syst Biol. 2007:56:879-86.

del Hoyo J, Collar NJ. HBW and BirdLife International illustrated checklist of birds of the world. Vol 1: Non-passerines. Barcelona: Lynx Edicions; 2014.

Dickinson EC, Remsen JV Jr (eds). The Howard and Moore complete checklist of the birds of the world, Fourth edn, vol. 1: Non-passerines. Eastbourne: Aves Press; 2013.

Eaton JA, van Balen B, Brickle NW, Rheindt FE. Birds of the Indonesian archipelago: greater Sundas and Wallacea. 2nd ed. Barcelona: Lynx Edicions; 2021.

Gill F, Donsker D, Rasmussen P (eds). IOC World Bird List (v10.2). 2020. http:// www.worldbirdnames.org. Accessed 24 Aug 2020.

Gwee CY, Christidis L, Eaton JA, Norman JA, Trainor CR, Verbelen P, et al. Bioacoustic and multi-locus DNA data of Ninox owls support high incidence of extinction and recolonisation on small, low-lying islands across Wallacea. Mol Phylogenet Evol. 2017;109:246-58.

Gwee CY, Eaton JA, Ng EYX, Rheindt FE. Species delimitation within the Glaucidium brodiei owlet complex using bioacoustic tools. Avian Res. 2019;10:36.

Haffer J. The history of species concepts and species limits in ornithology. Bull Br Ornithol Club. 1992;112A:107-58.

Holyoak DT. Nightjars and their allies: the Caprimulgiformes. Oxford: Oxford University Press; 2001.

Howard R, Moore A. A complete checklist of the birds of the world. 2nd ed. London: Academic Press; 1991.

Inskipp T, Lindsey N, Duckworth W. An annotated checklist of the birds of the Oriental region. Sandy: Oriental Bird Club; 1996.

King BF, Dickinson EC, Woodcock M. Field guide to the birds of South-east Asia. London: Collins; 1975.

Krabbe NK. A new species of Megascops (Strigidae) from the Sierra Nevada de Santa Marta, Colombia, with notes on voices of New World screech-owls. Ornitol Colomb. 2017;16:eA08.

Kroodsma DE. The diversity and plasticity of birdsong. In: Marler P, Slabbekoorn $\mathrm{H}$, editors. Nature's music: the science of birdsong. Amsterdam: Elsevier Academic Press; 2004. p. 108-31.

Marshall JT. Systematics of smaller Asian night birds based on voice. Ornithol Monogr. 1978;25:1-58.

Mayr E. The birds of Timor and Sumba. Bull Am Mus Nat Hist. 1944;83:123-94.

Mees GF. Caprimulgus macrurus Horsfield and related forms, a re-evaluation (Aves: Caprimulgidae). Proc K Ned Acad Wet (biol Med Sci) 1985;88:419-28.

Mees GF. The avifauna of Flores (Lesser Sunda Islands). Zool Meded. 2006;80:1-261.
Peters JL. Check-list of birds of the world, vol. 4. Cambridge: Museum of Comparative Zoololgy; 1940.

Rasmussen PC, Anderton JC. Birds of South Asia: the Ripley guide. Barcelona: Lynx edicions; 2005.

Rasmussen PC, Schulenberg TS, Hawkins F, Voninavoko R. Geographic variation in the Malagasy Scops-Owl (Otus rutilus auct.): the existence of an unrecognised species on Madagascar and the taxonomy of other Indian Ocean taxa. Bull Br Ornithol Club. 2000;120:75-102.

Robson C. A field guide to the birds of Southeast Asia. London: New Holland; 2000.

Rothschild L. Corrections and criticisms to the article on the avifauna of Yunnan. Novit Zool. 1927;33:398-400.

Rozendaal FG. Vocalizations and taxonomic status of Caprimulgus celebensis. Dutch Birding. 1990;12:79-81.

Sangster $G$. Integrative taxonomy of birds: the nature and delimitation of species. In: Tietze DT, editor. Bird species. Fascinating life sciences. Cham: Springer; 2018. p. 9-37.

Sangster G, Rozendaal FG. Systematic notes on Asian birds. 41. Territorial songs and species-level taxonomy of nightjars of the Caprimulgus macrurus complex, with the description of a new species. Zool Verh Leiden. 2004;350:7-45.

Sawilowsky SS. New effect size rules of thumb. J Mod Appl Stat Meth. 2009;8:597-9.

Sibley CG, Monroe BL. Distribution and taxonomy of birds of the world. New Haven: Yale University Press; 1990.

Wolters HE. Die Vogelarten der Erde. Lieferung 2. Hamburg: Paul Parey; 1976.

Jännes H. Bird Sounds of Goa \& South India. Compact disc and booklet. Helsinki: Early Bird Birding Tours; 2002.

Supari S. Bird songs of Singapore. Compact Disc. Singapore: Singapore Nature Society; 2003.

Sangster G, King BF, Verbelen P, Trainor CR. A new owl species of the genus Otus (Aves: Strigidae) from Lombok, Indonesia. PLoS ONE 2013;8:e53712.

Sharpe RB. A hand-list of the genera and species of birds. Vol. 3. London: British Museum; 1901.

Sangster G, Luksenburg JA. Declining rates of species described per taxonomist: slowdown of progress or a side-effect of improved quality in taxonomy? Syst Biol. 2015;64:144-51.

Howell SNG, Robbins MB. Species limits of the least pygmy-owl (Glaucidium minutissimum) complex. Wilson Bull. 1995;107:7-25.

Rasmussen PC, Allen DNS, Collar NJ, Demeulemeester B, Hutchinson RO, Jakosalem PGC, Kennedy RS, Lambert FR, Paguntalan, LM. Vocal divergence and new species in the Philippine Hawk Owl Ninox philippensis complex. Forktail. 2012;28:1-20.

Scharringa J. Birds of Tropical Asia 3. Third edition. DVD-ROM. Westernieland: Bird Songs International; 2005.

Chappuis C, Deroussen F, Warakagoda D. Indian bird sounds. Five Compact Discs and booklet. Hyderabad, India: Anne Chappuis; 2009.

\footnotetext{
Ready to submit your research? Choose BMC and benefit from:

- fast, convenient online submission

- thorough peer review by experienced researchers in your field

- rapid publication on acceptance

- support for research data, including large and complex data types

- gold Open Access which fosters wider collaboration and increased citations

- maximum visibility for your research: over $100 \mathrm{M}$ website views per year
}

At $\mathrm{BMC}$, research is always in progress.

Learn more biomedcentral.com/submissions 